\title{
Disaster Risk Reduction Education through Storytelling for Pre-School Children: A Case Study of Storytellers' Local Community in Lombok, West Nusa Tenggara
}

\author{
Yulia Hidayati ${ }^{1, *}$
}

\author{
${ }^{1}$ BPPAUD DIKMAS Nusa Tenggara Barat, Mataram, Indonesia \\ *Corresponding author.Email:yuliahidayati1507@gmail.com,yhid0001@student.monash.edu
}

\begin{abstract}
This paper presents a study on the disaster risk reduction education (DRRE) through storytelling for preschool-aged children by the local storytellers' community (later in this writing called as LSC) in Lombok, Indonesia. The conceptual framework used is narrative inquiry through the three commonplaces of sociality, temporality and place (Conelly and Clandinin, 2006). By exploring a case study as methodology, this writing draws on the case of two storytellers who actively demonstrates their skill for the aims of DRRE. The data was collected through the semi-structured interview and the analysis of storytelling video on their YouTube channel. The findings demonstrated that storytelling to improve disaster awareness shaped collaboratively through the three aspects of narrative inquiry. The way that story made, and its performance delivered depends on the children background, language and local values will act as valuable insight to further enrichment, together with the notion of using fun ways of delivering DRRE, namely, singing, props exploration and story-acting. Storytelling appears to be an effective technique to improve disaster awareness among young children. Thus, the mutual alliance between the government as the policymaker, the practitioners as those who engage in the practice and the academics as those who investigate the concepts, is expected

Keywords: Storytelling, disaster risk reduction education, preschool, narrative inquiry
\end{abstract}

\section{INTRODUCTION}

As one of the global countries that have a heavy risk of natural disaster, which is getting worse by the rapid urbanization, a high population, low economic growth, the imbalance of natural resources exploitation (Djalante, Garschagen, Thomalla, \& Shaw, 2017), Indonesia needs to take several roles to get the community aware of the further possible risks.

Therefore, the government strengthen the issue of disaster management by the existing national law number 24 of the year 2007. This law arranges the formal regulation regarding catastrophes and the needed supervision, as well as defines comprehensive cooperation among policymakers and related stakeholders. Correlatively, in article 26 of the law, the rights of citizens being mentioned, as the government essentially provide them with the relevant education and training regarding disasters. Thus, the president of Indonesia, Joko Widodo, has given instructions to include DRRE in the school curriculum (Tempo, 2019; Times, 2019).

Recently, the majority of DRRE studies have focused on six-years old children above rather than younger-age children, which clearly demonstrated by the methodological review study conducted by Johnson, Ronan, Johnston, \& Peace (2014). Johnson et al., (2014) only found one per cent of 35 relevant studies that concerned with children younger than six years old. The DRRE implementation vary, such as comical strips (Sharpe \& Izadkhah, 2014) to the making of disaster preparation bag for children (Gulay, 2010). Furthermore, with their unique capabilities, early-age children can support the community efforts' to lessening hazard and catastrophe risks (Fothergill, 2017). However, further research is required to shape a better understanding of how DRRE in an early childhood setting can encourage young children's awareness regarding disasters.

Applied by the LSC in Lombok, storytelling has become the primary medium for applying DRRE among preschoolaged children. The LSC's active contribution to disaster awareness has been mainly enhanced by the large-scale series of earthquakes that occurred in the region in the middle of 2018. The movement was initially purposed to entertain the earthquake victims, especially young children, in the evacuation camps. Over time, the storytelling activity turned into a regular action as part of DRRE for children in the broader community in Lombok. Thus, this current study purposes to discover DRRE through storytelling for 
preschool-aged children through their presented story and performance, in the framework of narrative inquiry. In doing so, an insight into the implementation of DRRE among early learners through community contribution is expected.

\section{THEORETICAL FRAMEWORK}

\subsection{DRRE for Preschool Children}

The potential for initiating and improving studies in DRRE for preschool-aged children is recognisably important, especially in the circumstances whereby those themes of studies are still lacking (Proulx \& Aboud, 2019). Therein lies the fact that in a disaster situation child can be intensely vulnerable, they own potential aptitudes can back-up the society to lessen the catastrophes' impacts (Fothergill, 2017). For instance, a primary school in Japan succeeded in attaining zero victim rate when a massive earthquake struck, after all the children successfully implemented what the school had taught them about DRRE, which was based on local wisdom (Kitagawa, 2015). This is in-line with the evidence demonstrated in the literature which found that improved knowledge of disaster through the DRRE process will most likely correspond to children's preparedness (Amri, Haynes, Bird, \& Ronan, 2018; Johnson et al., 2014) Many studies on the notion of DRRE has mentioned the circumstances in primary schools and above, otherwise, DRRE in the ECE setting is relatively inconsiderable. In their literature review on DRRE themes, Amri et al., (2018) found that less than one per cent of the research on DRRE focused on children under six years old. One of the practices is the innovative development of animated comic strips to teach kindergarten children in Iran about earthquakes (Sharpe \& Izadkhah, 2014). The way that kindergarten children were able to understand earthquake alertness by discussing it with their parents and peers can be defined as a favourable outcome. Gulay (2010) developed a DRRE program that focused on the practical things to put in an earthquake preparation bag. The children successfully mentioned some of the relevant objects to be included, such as food, flashlight, medicine and water. Lastly, a study in Sumba, Indonesia, mentioned how a DRRE program in an early childhood setting improved the knowledge and skills of the children (Proulx \& Aboud, 2019). Overall, DRRE should add to the preschool program as the results have indicated that the sooner DRRE is delivered, the more children's alertness of disasters will be positively impacted. Thus, in their review, Amri et al., (2018) argue that further studies of DRRE are required to support the implementation in the early stage.

\subsection{Storytelling and Narrative Inquiry: The Intersection}

Narratives are stories and tailed by storytelling as the way to communicate it. Further reasoning might apparently demonstrate through the following thoughts of narrative inquiry, which is:

"People shape their daily lives by stories of who they and others are and as they interpret their past in terms of these stories. Story in the current idiom, is a portal through which a person enters the world and by which their experience of the world is interpreted and made personally meaningful. Narrative inquiry, the study of experience as story, then, is first and foremost a way of thinking about experience". (Connelly \& Clandinin, 2006, p. 375)

In the means of considering relation among individuals and the narratives behind them, narrative inquiry provided by three commonplaces which act as a theoretical framework, namely temporality, sociality and place (Clandinin \& Connelly, 2000). In addition, 'the study of any one or combination of these commonplaces might well take place in some other form of qualitative inquiry. What makes a narrative inquiry is the simultaneous exploration of all three' (p. 79).

According to Connelly and Clandinin (2006, p. 479), temporality refers to 'events under study [that] are in temporal transition. Furthermore, temporal arrangements might vary according to two main themes, namely, events and actions, as a description of verbal and inscribed text (Maitlis, 2012, p. 492). In the provoking thought of Carr (1991), both allied individuals in the narrative process should be present in their own temporality of events, things and places. This means that the present life is the result of past experiences and impacts on the future and continuity of life.

The second commonplace is sociality. By means of sharing their experiences narratively, inquirers should concurrently come across social conditions. The social conditions discuss the circumstances which lead to the individual's experiences and actions (Clandinin \& Huber, 2010).

Thus, the last commonplace, which is the place, means 'the specific concrete, physical, and topological boundaries of place or sequences of places where the inquiry and events take place', as reasoned by Connelly and Clandinin (2006, p. 480). They recognise that 'all events take place someplace' (Connelly \& Clandinin, p. 481).

In their study on the employment of narrative as a method and as an instructional strategy, Coulter, Michael, \& Poynor (2007) conclude that understanding develops by means of a narrative when it is purposive and associated with a sustained discourse between 'telling' and 'doing', between stories, criticism and praxis (Ritchie \& Wilson, 2000, p. 172). The storytelling process then can be purposively 
transformed into a pedagogy that allows the storytellers and the listeners to interact through the exposed problems, which turn into solutions. Thus, this study intends to capture the field practice of storytelling as part of the LSC's contribution to DRRE.

\section{METHODOLOGY}

To explore the employment of storytelling as part of DRRE for preschool children by the LSC in Lombok, a case study was used as the methodology. A case study fits for a study that entails an in-depth examination of a multifaceted topic (s) in a specific geographic area with a limited number of subjects of interests (Berg, 2004). Stake (1995) adds that case study will empower the researcher to recognize the social circumstances, which in this research is the attempt from the local community to support DRRE through the views of the storyteller.

Considering the time limitation, the participants in this study comprised only two representatives' storytellers, namely Awan and Ana. Furthermore, in need of data triangulation, the researcher also briefly examined the video of a storytelling performance which is publicly available through the LSC's YouTube account. As argued by Yin (2018, p. 121), data triangulation contributes to enhancing the research, particularly in the notion of constructing validity. Thus, as another source, the existence of a relevant video will help the researcher in shaping the study conclusion.

\section{FINDINGS}

\subsection{Temporality: The transition of a story}

Supported by the narrative cases of research participants, the story in the realm of DRRE was formed through the idea of transitioning and continuity. According to the idea of narrative inquiry, the transition reflects how the story is shaped through the three dimensions of time, namely, past, present and future (Connelly \& Clandinin, 2006). The past events significantly have an impact on the present and further actions of the narrative, as demonstrated in the way in which Awan changed earthquake to another kind of catastrophe when demonstrating storytelling to children who had experienced earthquakes.

Yet, it is quite interesting to explore the way in which Awan captures reality differently from Ana. While Awan mentioned that the children have experienced emotional trauma, Ana found that adults suffer more than children as a result of trauma. Consequently, Awan attempted to find the proper way to conduct storytelling for the children, while Ana argued that storytelling for DRRE is basically like other kinds of storytelling. The different perceptions they demonstrated indicates that even though they intersect into the same object, their experiences are grounded differently, which continuously affects them in disparate ways (Hutchinson, 2015). Taken together through their personal narratives, which demonstrated how Awan initiated the acts of storytelling, it could be said that he reflects on Dewey's concept of experience in that his 'personal dimension reflects the internal conditions of interaction and the social dimension reflects the external conditions of interaction' (Conelly \& Clandinin, 2000, as cited in Hutchinson, 2015, p. 11). In this sense, although they have different perceptions, both Awan and Ana still took together in their interaction in the time temporality.

\subsection{Sociality: Collaboration as the Key Point}

The story presented is the result of the collaborative work of individuals. The two storytellers demonstrated similarities in the ways they described how the external stakeholders, such as NGOs and government institutions had influenced their story context. This demonstrates how they are concerned with building stories for young children that will be culturally and socially understood according to the relevant events (Clandinin, Caine, Lessard, \& Huber, 2016). As the final story is a mix of socio-cultural substance and practical guidance for DRRE, it demonstrates how the possibility of institutional, social and cultural narratives might signify the harmonious of societal narratives (Hutchinson, 2015). Even though in some ways the collaboration might appear intangible since the LSC is merely adapting the established DRRE guidelines of the NGOs and government organizations to their own performance narratives, still, it can be defined as silent collaborative work (Clandinin \& Connelly, 1995).

The story's context is undeniably formed by social circumstances (Connelly \& Clandinin, 2006). As demonstrated by the way in which the storytellers explore the local name of the character, place and plot of the performed story, their attempts to provide narratives that are close to the children's reality is recognizable.

\subsection{Place: Its impact on storytelling acts}

Every place has an impact on the notion of narrative inquiry, which correlates with the idea that every single inquiry and event occurs in a place (D. Jean Clandinin \& Connelly, 2000; Hutchinson, 2015). Explicitly, place in the narrative concept refers to 'the specific concrete, physical, and topological boundaries of place where the inquiry and events take place' (Connelly \& Clandinin, 2006, pp. 480481). In this study, Awan initially evidenced how sharing narratives about catastrophe to those children who have previously experienced ones and are still living in 
evacuation camps appears to be a tough challenge, since the children are still in psychological trauma.

Having experienced such an event, he decided to consider the 'place' that the event occurred, so that it back to the notion of how he will flexibly re-create the proper narratives. As such, this reflects on Hutchinson's (2015) argument that the process of constructing meaning from narratives will shape the experience that is obtained in a place, so, rather than focus on the disaster term that needs to be explained, the storytellers might focus more on the ideas of a story as entertainment in the sense of optimism and survival (Rae, 2016).

\subsection{Performing and Exploring the Story for the Aim of Disaster Awareness}

\subsubsection{Story transition as the phase of temporality}

As argued by Connelly and Clandinin (1990), numerous studies on narrative inquiry have explained the entry dialogue into the field context. In this study, a negotiation is witnessed in the transition from Ana and Awan's greeting to the beginning of the performed story. Particularly for Ana, this starting point is crucial to attract the children's attention as well as to create the first impression that aims to make them feel welcomed and appreciated. This idea correlates with Hogan's (1988, as cited in Clandinin \& Connelly, 2000) opinion on the way to empower relationships among individuals in the narrative inquiry, namely through equality, kindness, consideration and feeling of togetherness. In practice, the way in which Awan used a joyful greeting and Ana used an initial song, demonstrate the manner of mutual transaction between the children and the storytellers (Connelly \& Clandinin, 1990). The further phase refers to build the stories alive, which demonstrates storytellers' attempt to describe the main theme of the story and include some practical actions (Connelly \& Clandinin, 1990). One of the stories they presented, titled 'Papuq Aman', presents the plot of an elderly protagonist who is respected by other character as his charm to the DRRE knowledge, which also demonstrated the involvement of local value and character, in a time transitional of past, present and future (Connelly \& Clandinin, 2006). As mentioned, and strengthened by the provided video, Awan and Ana as the storytellers started by the past moment that captured the previous disaster in a story scene and continued to the present conflict of the story character and ended with optimism for the future as their readiness to further possible disasters. The temporality is shaped by the way in which performed narratives demonstrate a chronological transition (Connelly \& Clandinin, 2006).

\subsubsection{Plaxe}

The notion of place is significantly recognized, as every narrative occur in a place (Connelly \& Clandinin, 2006, p. 481). Ana believed that the place setting would likely impact on the success of the storytelling, so either the specific forms of physical that surrounded (Clandinin \& Huber, 2010). For instance, she thought that the success of the story would more likely be achieved in outdoor situations where the children can be freer to express themselves, whereas, in an indoor situation, the children's movement will be more limited.

\subsubsection{The strength of collaboration that reflects sociality}

The aspect of sociality in the storytelling practice is captured in the interviews and strengthened by the provided video. The collaboration between all the storytellers demonstrated cooperation and understanding of their respective roles, not only that, the smoothness of their dialogue and performance confirmed the practice that they have been through.

The aim of storytelling practice conducted by LSC is to narratively shape the context of DRRE for young children by means of collaborative performance. Moreover, as active individuals, young children as the audience already bring their own 'narratives' that involve their identity (Haydon, Browne, \& van der Riet, 2018). Thus, the way in which the storytellers respect the children stories is by conducting question and answer sessions.

\section{CONCLUSION}

Based on the framework of narrative inquiry, this research was carried out by including Awan and Ana's narrative case as storytellers in the LSC in Lombok. The three commonplaces of narrative inquiry, namely place, sociality and temporality are framed through the study findings. Therefore, the findings of this research demonstrate that the three aspects collaboratively shaped the stories and how they were performed appropriately. The story was influenced by the relevant disaster awareness guidance from reputable NGOs, as well as government officials, and aimed to present valuable and policy-based material. However, in practice, the story needed to be flexible to adapt it to the actual situation of the viewers as well as the context of the storytelling events. For instance, the change of the term earthquake to be delivered to the children who have experienced it, demonstrated the story temporality, as well as the way in which it was performed. Moreover, it is necessary to initially consider who are the viewers will be and their background with regards to the storytelling event, especially in the circumstances of DRRE. 
A further outcome is the usage of local language and local values, which strengthened by the video of storytelling performance. This reflects the LSC's attempt to provide a narrative that is most likely to the reality of the young children so that they can relate it to their situation. Furthermore, the various ways of delivering storytelling in the circumstances of DRRE are more likely to be in the form of light-hearted activities, which are intended to attract the children's attention. Therefore, the acts of the storytellers in story-acting, singing, dancing and playing instruments have a single intention, which is to deliver storytelling on disaster risk awareness in a fun and meaningful way.

This study indicates that with regard to the emerging issue of disaster education in Indonesia, storytelling appears to be an effective technique to improve disaster awareness among young children. The practitioners, or in this case, the LSC thus needs to be encouraged to improve their actions and inspired with relevant actions, such as story training and collaboration with school teachers, so that DRRE will be available to more children and more professional who act together. Practically, it has exposed the significance of a mutual alliance between the government as the policymaker, the practitioners as those who engage in the practice and the related academics as those who investigate the theories and meanings. Expectedly, this study might initiate action to expand the DRRE movement as well as improve the quality of information available.

\section{REFERENCES}

Amri, A., Haynes, K., Bird, D. K., \& Ronan, K. (2018). Bridging the divide between studies on disaster risk reduction education and child-centred disaster risk reduction: A critical review. Children's Geographies, 16(3), 239-251. Retrieved from https://doi.org/10.1080/14733285.2017.1358448. doi:10.1080/14733285.2017.1358448

Berg, B. L. (2004). Qualitative research methods for the social sciences (5th ed.). Boston, MA : Pearson.

Carr, D. (1991). Time, narrative, and history (1st Midland book ed. ed.). Bloomington: Indiana University Press.

Clandinin, D. J., \& Connelly, F. M. (1995). Teachers' professional knowledge landscapes. New York: Teachers College Press.

Clandinin, D. J., \& Connelly, F. M. (2000). Narrative inquiry: experience and story in qualitative research (1st ed. ed.). San Francisco: Jossey-Bass Publishers.

Clandinin, D. J., \& Huber, J. (2010). Narrative inquiry. In B. McGaw, E. Baker, \& P. Peterson (Eds.),
International encyclopedia of education ( $3 r d$ ed.). New York: Elsevier.

Clandinin, J., Caine, V., Lessard, S., \& Huber, J. (2016). Engaging in narrative inquiries with children and youth. London: Routledge.

Connelly, F. M., \& Clandinin, D. J. (1990). Stories of experience and narrative inquiry. Educational

Researcher, 19(5), 2-14. Retrieved from

http://www.jstor.org.ezproxy.lib.monash.edu.au/stable/ 1176100. doi:10.2307/1176100

Connelly, F. M., \& Clandinin, D. J. (2006). Narrative Inquiry. In J. L. Green, G. Camilli, \& P. B. Elmore (Eds.), Handbook of complementary methods in education research (pp. 375-385). United States: Lawrence Erlbaum.

Coulter, C., Michael, C., \& Poynor, L. (2007).

Storytelling as Pedagogy: An Unexpected Outcome of Narrative Inquiry. Curriculum Inquiry, 37(2), 103-122. Retrieved from https://doi.org/10.1111/j.1467873X.2007.00375.x.

Djalante, R., Garschagen, M., Thomalla, F., \& Shaw, R. (2017). Introduction: Disaster risk reduction in Indonesia: Progress, Challenges, and Issues. In R. Djalante, M. Garschagen, F. Thomalla, \& R. Shaw (Eds.), Disaster Risk Reduction in Indonesia: Progress, Challenges, and Issues. Switzerland: Springer.

Fothergill, A. (2017). Children, youth, and disaster. Oxford: Oxford University Press.

Gulay, H. (2010). An earthquake education program with parent participation for preschool children. Educational Research and Review, 5(10), 624-630.

Haydon, G., Browne, G., \& van der Riet, P. (2018). Narrative inquiry as a research methodology exploring person centred care in nursing. Collegian, 25(1), 125129. Retrieved from https://doi.org/10.1016/j.colegn.2017.03.001. doi:10.1016/j.colegn.2017.03.001

Hutchinson, D. A. (2015). Coming to understand experience: Dewey's theory of experience and narrative inquiry. Journal of Thought, 49(3-4), 3-17.

Johnson, V. A., Ronan, K., Johnston, D. M., \& Peace, R. (2014). Evaluations of disaster education programs for children: A methodological review. International Journal Disaster Risk Reduct., 9, 107-123. doi:10.1016/j.ijdrr.2014.04.001 
Kitagawa, K. (2015). Continuity and change in disaster education in Japan. History of Education, 44(3), 371390. Retrieved from https://doi.org/10.1080/0046760X.2014.979255. doi:10.1080/0046760X.2014.979255

Maitlis, S. (2012). Narrative analysis. In G. Symon \& C. Cassell (Eds.), Qualitative organizational research: Core methods and current challenges (pp. 492-510):

SAGE Publications Ltd.

Proulx, K., \& Aboud, F. (2019). Disaster risk reduction in early childhood education: Effects on preschool quality and child outcomes. International Journal of Educational Development, 66, 1-7. Retrieved from http://www.sciencedirect.com/science/article/pii/S0738 059317306120.

doi:https://doi.org/10.1016/j.ijedudev.2019.01.007

Rae, A. (2016). Tales of disaster: The role of accident storytelling in safety teaching. Cognition, Technology \& Work, 18(1), 1-10. doi:10.1007/s10111-015-0341-3

Ritchie, J. S., \& Wilson, D. E. (2000). Teacher narrative as critical inquiry: Rewriting the script. New York: Teachers College Press.

Sharpe, J., \& Izadkhah, Y. (2014). Use of comic strips in teaching earthquakes to kindergarten children. Disaster Prevention and Management, 23(2), 138-156. doi:10.1108/DPM-05-2013-0083

Stake, R. E. (1995). The art of case study research. Thousand Oaks: Sage Publications.

Tempo. (2019). Jokowi: Disaster management curriculum introduced this month. Tempo. Retrieved from https://en.tempo.co/read/1161007/jokowi-disastermanagement-curriculum-introduced-this-month

Times. (2019). Indonesia to teach kids disasterreadiness. The Straits Times. Retrieved from https://www.preventionweb.net/news/view/63076

Yin, R. K. a. (2018). Case study research and applications : design and methods (Sixth edition. ed.). Thousand Oaks, California: SAGE Publications, Inc. 